Suska Journal of Mathematics Education (p-ISSN: 2477-4758 | e-ISSN: 2540-9670)

Vol.4, No. 2, 2018, Hal. 88 - 99

\title{
Kualitas Hasil Belajar Statistika Siswa MTs yang dibelajarkan dengan Pendekatan Problem Posing
}

\author{
Nuralam$^{1}$, Tarmizi Gadeng ${ }^{2}$ \\ ${ }^{1}$ Mathematics Education Department, Universitas Islam Negeri Ar-Raniry Banda Aceh \\ ${ }^{2}$ Mathematics Education Department, Universitas Mubammadiyah Aceh \\ e-mail: ${ }^{1}$ nuralam@ar-raniry.ac.id; ${ }^{2}$ tarmizi.gadeng@unmuha.ac.id
}

\begin{abstract}
ABSTRAK. Tinggi dan rendah perolehan hasil belajar matematika siswa dipengaruhi oleh faktor internal dan eksternal. Salah satu faktor eksternal yang berelasi dengan perolehan hasil belajar matematika adalah pendekatan pembelajaran. Umumnya pendekatan yang digunakan kurang melibatkan siswa dalam belajar matematika, sehingga berakibat perolehan hasil belajar matematika kurang optimal. Salah satu solusi yang memberikan kontribusi bagi pelibatan siswa dengan membelajarkan matematika melalui pendekatan problem posing. Adapun tujuan penelitian ini adalah mengetahui: (1) hasil belajar statistika siswa yang diajarkan melalui pendekatan problem posing dibandingkan dengan yang diajarkan melalui pendekatan pembelajaran langsung dan (2) respon siswa setelah proses pembelajaran statistika dengan pendekatan problem posing. Penelitian ini menggunakan penelitian kuasi eksperimen dengan rancangan post test only control group design. Populasi penelitian adalah seluruh siswa kelas VIII MTsS Darul Hikmah Aceh Besar dan sampel diambil dengan teknik total sampling. Data dikumpulkan dengan tes hasil belajar statistika dan angket respon. Teknik analisis data menggunakan uji t untuk data tes dan data angket respon melalui analisis kriteria skor rata-rata. Berdasarkan hasil analisis data tes diperoleh bahwa thitung $>$ $\mathrm{t}_{\text {tabel yaitu }} 2,45>1,70$. Dari hasil data angket skor rata-rata sebesar 3,29. Disimpulkan bahwa hasil belajar statistika siswa yang diajarkan melalui pendekatan problem posing lebih tinggi daripada yang diajarkan melalui pendekatan pembelajaran langsung. Dan angket respon siswa setelah proses pembelajaran statistika dengan pendekatan problem posing dalam kategori sangat positif.
\end{abstract}

Kata kunci: pendekatan pembelajaran, pendekatan problem posing, pendekatan pembelajaran langsung, hasil belajar statistika siswa, respon belajar siswa.

ABSTRACT. High and low acquisition of students' mathematics learning outcomes is
influenced by internal and external factors. External factors of concern are related learning
approaches so students are easy to learn mathematics. There is a tendency for the role of
students to be more passive and teachers to be more active in the process of learning
mathematics. This condition results in low acquisition of mathematics learning outcomes.
One alternative solution is to teach students through the problem posing approach, so as
to contribute to the involvement of students in learning mathematics. The purpose of this
study was to find out: (1) statistics learning outcomes of students taught through the
problem posing approach were higher than those taught through direct learning
approaches and (2) student responses after the statistical learning process with a problem
posing approach. This study uses a quasi-experimental study with a control group only
design post test design. The population is students of MTsS Darul Hikmah Aceh Besar
grade VIII and the sample was total sampling. Data were collected by statistical learning
outcomes and response questionnaires. Data analysis techniques used test for test data 
and response questionnaire data through analysis of average score criteria. Based on the results of the analysis of the test data obtained that $t_{\text {count }}>t_{\text {table }}$ is $2,45>1,70$. From the results of the questionnaire data the average score was 3.29. It was concluded that the statistical learning outcomes of students taught through the problem posing approach were higher than those taught through direct learning approaches. And the student response questionnaire after the statistical learning process with the problem posing approach in the very positive category

Keywords: Learning approach, problem posing approach, direct learning approach, student statistical learning outcomes, student learning responses

\section{PENDAHULUAN}

Ilmu pengetahuan berkaitan erat dengan matematika di jaman teknologi saat ini. Banyak hal di lingkungan sekitar kita yang selalu berelasi dengan matematika. Konsep matematika dapat dicermati dalam kehidupan nyata di masyarakat, misalkan mencari nomor rumah penduduk, tata kelola nomor telepon, perniagaan, penukaran mata uang, pengukuran, dan sebagainya. Contohnya dalam kehidupan sehari-hari, manusia senantiasa melakukan praktek perhitungan dan kegiatan ini tentu akan bersentuhan dengan konsep matematika. Karena kebermanfaatan matematika sedemikian rupa tersebut, maka konsep dasar matematika yang diajarkan kepada siswa harus benar-benar memperhatikan kesesuaian antara hakikat matematika dan bagaimana matematika itu dibelajarkan kepada siswa. Salah satu bentuk perwujudan bagaimana pentingnya matematika tersebut, pemerintah telah menjadikan matematika sebagai salah satu mata pelajaran yang harus dipelajari oleh siswa sejak sekolah dasar hingga ke perguruan tinggi. Bagaimana potensi matematika yang dipelajari dan dikuasai oleh siswa, dapat diketahui melalui perolehan hasil belajarnya. Tinggi rendahnya perolehan hasil belajar matematika siswa sebagai bagian yang tidak dapat dipisahkan dari proses pembelajaran matematika di sekolah. Dinamika perolehan hasil belajar matematika tersebut memberikan inspirasi dan peluang bagi tenaga pendidik untuk dapat berkreasi dan berinovasi dalam mengembangkan pembelajaran matematika. Inspirasi dan peluang dari pendidik matematika tersebut akan memberikan implikasi kepada siswa sebagai pusat pembelajaran sehingga mereka terlibat aktif dalam pembelajaran dan secara signifikan akan mempengaruhi sifat dan tingkat pembelajaran siswa (Nuralam \& Eliyana, 2017).

Eksistensi siswa dalam mempelajari matematika dapat dicermati melalui perolehan hasil belajar matematikanya. Hasil belajar matematika adalah perubahan perilaku peserta didik akibat belajar matematika. Menurut Purwanto (2009) bahwa perubahan perilaku disebabkan seseorang mencapai penguasaan atas sejumlah bahan yang diberikan dalam proses belajar mengajar. Oleh karena itu, guru harus memiliki gagasan kreatif dan perlu menciptakan suasana pembelajaran yang memungkinkan bagi siswa agar mereka mudah belajar matematika. Sehingga pengetahuan atau ilmu dapat dipahami oleh siswa. Menurut Sudjana (1999) bahwa hasil belajar adalah kemampuan-kemampuan yang dimiliki peserta didik setelah ia menerima pengalaman belajarnya. Hasil belajar siswa dapat diukur dengan menggunakan alat evaluasi yang biasanya disebut tes hasil belajar. Sependapat dengan itu, Hudojo (1990) menyatakan bahwa tingkat keberhasilan atau penguasaan seorang siswa terhadap bidang studi matematika setelah menempuh proses belajar mengajar yang terlihat pada nilai yang diperoleh dari tes hasil belajarnya.

Hasil belajar matematika itu memegang peranan penting, karena memberikan sajian informasi tentang pencapaian tujuan belajar matematika tertentu. Sunarto \& Hartono (2006) menyatakan bahwa hasil belajar merupakan kemampuan kognitif dari perpaduan faktor pembawaan dan pengaruh lingkungan. Menurut Gagne (1979) bahwa hasil belajar 
merupakan perubahan perilaku individu yang diinginkan berdasarkan variabel bawaannya melalui perlakuan pembelajaran tertentu. Informasi perubahan perilaku belajar dari individu tersebut baik dari aspek pengetahuan, sikap dan keterampilan dapat dimanfaatkan sebagai bahan evaluasi dan pertimbangan pembelajaran matematika selanjutnya. Sehingga guru dapat menyusun dan membina kegiatan siswa lebih lanjut dalam pembelajaran matematika berikutnya.

Permasalahan yang terjadi dalam mempelajari matematika, masih banyak siswa yang perolehan hasil belajar matematika tidak memuaskan. Ada kecenderungan dalam belajar matematika lebih menekankan pada menghafal tanpa memahaminya. Menurut Ruseffendi (2005) bahwa belajar matematika lebih banyak menghafal berdampak dalam memahami mata pelajaran matematika. Persoalan hasil belajar matematika siswa yang berada pada posisi yang kurang memuaskan tersebut perlu mendapat perhatian semua pihak, juga terjadi di daerah Aceh Besar. Berdasarkan data di BNSP Kemendikbud (2015) diperoleh bahwa peringkat hasil ujian nasional matematika SMP/MTs di Aceh Besar tahun 2015 menunjukkan posisi MTsS Darul Hikmah Aceh Besar menempati urutan ke 17 dari 30 sekolah MTsN/MTsS di Aceh Besar dengan rata-rata 51,79. Rata-rata ini lebih rendah dari tahu sebelumnya yaitu 60,93

Perolehan nilai UN matematika tersebut memberikan kontribusi juga pada pencapaian hasil belajar statistika di sekolah teliti. Dari hasil tes materi statistika diperoleh skor rata-rata sebesar 36,52 dan perolehan ini masih tergolong rendah. Kondisi ini menunjukkan bahwa materi statistika masih dianggap tidak mudah diserap oleh siswa. Materi statistika adalah salah satu materi yang dipelajari oleh siswa kelas VIII SMP/MTs. Statistika merupakan suatu ilmu yang berkenaan dengan data, sedang statistik adalah data, informasi, atau hasil penerapan algoritma statistika pada suatu data. (Walpole, 1993; Kurniawan, 2003). Dari kumpulan data, statistika dapat digunakan untuk menyimpulkan atau mendeskripsikan data. Materi ini sangat penting untuk dipelajari karena materi statistika sangat berguna dalam kehidupan sehari-hari, misalnya mencari nilai rata-rata rapor siswa, membuat grafik pendapatan dan pengeluaran seorang pengusaha tiap bulannya, dan perhitungan indeks prestasi.

Mencermati kondisi tersebut, banyak faktor yang terkait baik secara internal maupun eksternal. Dilihat dari faktor internal, ini menunjukkan bahwa ada yang terjadi pada diri siswa terutama kemampuan belajar matematika, kemampuan menyerap pelajaran, berinteraksi sesama siswa dan berinteraksi dengan guru. Disisi faktor eksternal yaitu metode pembelajaran, fasilitas belajar, kurikulum dan sarana prasarana sekolah. Jadi baik faktor internal maupun faktor eksternal memberikan kontribusi bagi hasil belajar matematika siswa. Salah satu faktor eksternal yang menjadi perhatian peneliti adalah metode pembelajaran yang fokusnya pada pendekatan pembelajaran yang guru gunakan dalam membelajarkan matematika.

Pemilihan pendekatan yang tepat dalam proses pembelajaran matematika akan memudahkan siswa dalam mempelajari materi yang disajikan guru, sehingga hasil belajar siswa akan lebih optimal. Oleh karena itu, guru sebaiknya dapat mempergunakan pendekatan pembelajaran yang dapat membuat siswa lebih aktif dan memotivasi mereka dalam proses pembelajaran. Djamarah \& Aswan (2002) menyatakan bahwa pendekatan pembelajaran yang tepat akan sangat menentukan kualitas hasil belajar.

Pendekatan pembelajaran pada penelitian ini sebagai suatu prosedur yang digunakan dalam membahas suatu bahan pembelajaran matematika untuk mencapai tujuan pembelajaran. Menurut Ahmad (2012) bahwa pendekatan pembelajaran bersifat aksiomatis 
sebagai suatu keyakinan yang dianggap benar tanpa harus dibuktikan. Hal ini didasarkan atas pengetahuan, teori, ideologi, dan pengalaman sebelumnya. Keyakinan tersebut sebagai landasan berpijak dalam menentukan keputusan mengenai proses pembelajarannya. Suatu pendekatan memerlukan satu atau lebih metode pembelajaran untuk mendukung implementasi pendekatan tersebut. Pendekatan pembelajaran dapat digunakan untuk menetapkan strategi dan langkah-langkah pembelajaran demi tercapainya tujuan pembelajaran. Penelitian ini melakukan dua perlakuan yang berbeda untuk membelajarkan materi statistika kepada siswa yaitu 1) pendekatan problem posing dan 2) pendekatan pembelajaran langsung.

Pertama, pendekatan problem posing. Pendekatan ini berpusat kepada siswa (student centered approaches). Pendekatan pembelajaran yang berpusat pada siswa tersebut berlandaskan pada aliran kognitivisme. Menurut Hudojo (1990) bahwa aliran kognitivisme ini menganggap inti dari belajar adalah belajar dengan pengertian. Pengakuan problem posing sebagai pendekatan dalam pembelajaran matematika dan dipakai sejak 1989 oleh National Council of Teacher of Mathematics (NCTM) merupakan bagian dari reformasi pendidikan matematika. Sejak tahun tersebut pendekatan ini mulai disosialisasikan dalam berbagai media seperti buku, jurnal dan menjadi bahan pembicaraan dari pakar pendidikan matematika dan tentu berdampak pada reformasi pendidikan matematika di Indonesia. Beberapa hasil penelitian yang telah dilakukan (Işik et al, 2011; Rosli et al, 2013; Juano \& Pardjono, 2016; Afgani et al, 2016; Daryati et al, 2018) berkaitan dengan pendekatan problem posing dalam pembelajaran matematika yang menunjukkan kontribusi positif bagi kualitas perolehan hasil belajar, kemampuan matematika tertentu, bahkan juga berelasi dengan perilaku belajar tertentu.

Pendekatan problem posing merupakan salah satu pendekatan untuk meningkatkan kemampuan menganalisa atau informasi yang terdapat dari soal-soal matematika, Karena pendekatan problem posing menuntun siswa untuk membuat pernyataan dari informasi yang diberikan tersebut. Selain itu, pendekatan problem posing dapat melatih siswa untuk membuat soal dari situasi yang diberikan sehingga siswa akan terbiasa dalam menghadapi dan menyelesaikan soal. Menurut Afriansyah (2017) bahwa siswa dapat memperoleh pemahaman konsep dan keterampilan yang baik ketika dihadapkan suatu masalah matematik dan guru pun dapat dengan mudah melakukan evaluasi sesuai dengan kemampuan pengajuan soal yang dimiliki siswa. Siswa ditempatkan sebagai subjek belajar dalam pendekatan problem posing. Posisi siswa tersebut menjadi strategis dalam mengembangkan potensi rasa ingin tahu dan berusaha dalam memahami lingkungannya. Dominasi siswa dalam proses pembelajaran matematika memberikan kesempatan kepada mereka untuk menganalisis permasalahan permasalahan yang ada dengan serangkaian kegiatan-kegiatan yang lebih bermakna yang diciptakan oleh guru. Kegiatan tersebut akan membuka wawasan dan kemampuan matematika siswa agar berkembang secara optimal.

Menurut Silver \& Cai (1996) ada tiga tipe aktivitas kognitif dalam pendekatan problem posing, yaitu: 1) pre-solution posing, 2) within solution posing; dan 3) post solution posing. Tiga tipe tersebut dapat digunakan oleh guru matematika dengan menyesuaikan tingkat kecerdasan siswanya. Pertama, tipe pre-solution posing. Tipe pertama ini menempatkan siswa untuk membuat atau merumuskan pertanyaan dan jawaban berdasarkan pernyataan yang dibuat oleh guru. Jadi, yang diketahui pada soal itu dibuat guru, sedangkan siswa membuat pertanyaan dan jawabannya sendiri. Kedua, tipe within solution posing. Tipe kedua ini menempatkan siswa agar dapat memecahkan pertanyaan tunggal dari guru menjadi sub-sub pertanyaan yang relevan dengan pertanyaan guru. Ketiga, tipe post solution posing. Tipe ketiga ini adalah tipe yang tinggi dan memiliki tantangan yang berbeda dalam pengajuan soal 
matematika siswa. Siswa membuat soal yang sejenis dan menantang seperti yang dicontohkan oleh guru. Jika guru dan siswa siap maka siswa dapat diminta untuk mengajukan soal yang menantang dan bervariasi pada materi matematika yang disajikan guru. Siswa harus bisa menemukan jawabannya. Jika siswa tidak dapat dengan mudah menemukan jawaban dari pengajuan soal yang dibuatnya, maka guru dapat bertindak scaffolding atau memberikan bantuan bimbingan belajar secukupnya. Dan guru harus menguasai materi matematika dengan baik.

Sementara berkaitan dengan pengalam siswa dalam pengajuan soal, menurut Pittalis et al (2004) bahwa pendekatan problem posing dapat digolongkan dalam bentuk tiga pengalaman, yaitu: 1) free-situation (situasi bebas), pada situasi ini peserta didik membuat soal tanpa ada ada batasan aturan dalam membuat soal; 2) semi-structured situation (situasi semi terstruktur), pada situasi ini peserta didik membuat soal yang sejenis dengan masalah yang diberikan guru atau peserta didik membuat soal berdasarkan atas gambar dan diagram yang diberikan guru; dan 3) structured problem-posing situation (situasi problem posing terstruktur), pada situasi ini peserta didik membuat soal dengan memformulasikan kembali soal yang telah diselesaikan atau dengan mengubah kondisi atau pertanyaan dari soal yang diberikan tersebut. Penelitian ini lebih menekankan pada tipe kedua, yaitu semi-structured situation (situasi semi terstruktur) dan dilakukan dengan mengelompokkan siswa secara kooperatif pada kelompok kecil sebanyak 4-5 siswa per kelompok.

Pendekatan problem posing dalam membelajarkan matematika sekolah memiliki langkah-langkah pembelajaran tertentu dan menekankan pada aktivitas pengajuan soal. Menurut Brown \& Walter (2005) bahwa ada lima langkah pendekatan problem posing yaitu: 1) choosing a starting point, 2) listing attributes; 3) what-if-not-ing; 4) question asking or problem posing; dan 5) analyzing the problem. Lima langkah tersebut saling berkaitan satu sama lain. Pertama, choosing a starting point (memilih titik awal), bahwa kegiatan awal ini guru menyajikan pengetahuan matematika tertentu kepada siswa. Pengetahuan matematika dapat berupa gambar, teorema, soal, dan sebagainya. Kedua, listing attributes (mendaftar sifat-sifat), bahwa siswa diminta untuk mendaftar sifat-sifat yang dimiliki oleh pengetahuan matematika yang disajikan tersebut. Hal yang diharapkan pada tahap ini adalah siswa mendaftar sebanyak mungkin sifat-sifat yang ada. Ketiga, what-if-not-ing (pertanyaan bagaimanakah jika tidak), bahwa Guru meminta siswa untuk membuat pertanyaan mengenai sifat-sifat yang telah mereka daftar. Contoh pertanyaan yang mungkin dapat ditanyakan berupa bagaimana jika tidak sifat tersebut tidak dimilikinya. Pada langkah ini, siswa dapat membuat daftar sifat lain sebagai jawaban atas pertanyaan tersebut. Keempat, question asking or problem posing (membuat pertanyaan atau problem posing), bahwa guru meminta siswa untuk membuat pertanyaan terkait jawaban atas pertanyaan bagaimana jika tidak. Tujuan langkah ini adalah siswa dapat membuat sebanyak mungkin pertanyaan. Dan kelima, analyzing the problem (menganalisis masalah), bahwa siswa diminta untuk menganalisis masalah kemudian mereka memecahkannya.

Kedua, pendekatan pembelajaran langsung. Pendekatan pembelajaran langsung merupakan pendekatan pembelajaran yang berpusat kepada guru (teacher centered approaches). Pendekatan pembelajaran yang berpusat pada guru tersebut berlandaskan pada aliran behaviorisme. Menurut Schunk (2012) bahwa aliran behaviorisme menekankan pada proses pembentukan asosiasi-asosiasi antara stimulus dan respons yang dapat diukur dan diamati dalam pembelajaran. Karena berpusat pada guru maka kegiatan pembelajaran sebagian besar guru yang lebih aktif daripada siswa. Komunikasi lebih banyak satu arah saja daripada banyak arah. Siswa lebih banyak mendengarkan sajian materi dari guru yang sudah jadi. Sajian materi yang sudah jadi memberikan dampak bahwa kegiatan pembelajaran yang 
dilakukan guru tersebut, diupayakan agar dapat menjamin keterlibatan siswa dalam memperhatikan, mendengarkan, dan tanya jawab. Pengaturan lingkungan tersebut mengacu pada tugas dan memberi harapan agar siswa dapat mencapai tujuan pembelajaran statistika. Akibatnya proses pembelajaran statistika di kelas menjadi proses mengikuti langkahlangkah aturan serta contoh-contoh yang diberikan oleh guru matematika.

Pendekatan pembelajaran langsung dalam membelajarkan statistika pada dasarnya mengikuti pola-pola pembelajaran secara umum. Menurut Kardi \& Nur (2000) bahwa ada delapan langkah pendekatan pembelajaran langsung, yaitu: 1) menyampaikan tujuan dan mempersiapkan siswa; 2) presentasi dan demonstrasi; 3) mencapai kejelasan; 4) melakukan demonstrasi; 5) mencapai penguasaan dan pemahaman; 6) berlatih; 7) memberikan latihan terbimbing; 8) mengecek pemahaman dan memberikan umpan balik. Delapan langkah pembelajaran tersebut saling berelasi satu sama lain dipaparkan berikut ini.

Pertama, menyampaikan tujuan dan menyiapkan siswa. Tujuan awal ini untuk menarik dan memusatkan perhatian siswa untuk berperan serta dalam pembelajaran dan mengingatkan kembali pengalaman belajar awal yang telah dimiliki sebelumnya yag relevan dengan materi yang akan dipelajari. Kedua, presentasi dan demonstrasi. Kegiatan ini melakukan presentasi atau demonstrasi pengetahuan dan keterampilan, sehingga informasi sejelas mungkin dapat disajikan dan mengikuti langkah-langkah demonstrasi yang efektif. Ketiga, mencapai kejelasan. Kegiatan ini menekankan bahwa kemampuan guru memberikan informasi yang jelas dan spesifik kepada siswa. Keempat, melakukan demonstrasi. Kegiatan ini guru mendemonstrasikan suatu konsep atau keterampilan dengan sepenuhnya menguasai konsep atau keterampilan tersebut dan berlatih melakukan demonstrasi untuk menguasai komponen-komponennya. Kelima, mencapai penguasaan dan pemahaman. Kegiatan ini menekankan pengamatan perilaku belajar yang benar, agar penguasaan dan pemahaman siswa dapat diamati dari setiap tahapan demonstrasi yang dilakukan oleh guru. Keenam, berlatih. Kegiatan ini menekankan latihan insentif dengan memperhatikan aspek-aspek penting dari keterampilan atau konsep matematika yang didemonstrasikan oleh guru. Ketujuh, memberikan latihan terbimbing. Kegiatan ini guru mempersiapkan latihan soal yang terbimbing. Siswa dilibatkan dalam menyelesaikan soal dan menerapkan pengetahuan dan keterampian yang telah dimilikinya pada situasi baru. Dan kedelapan, mengecek pemahaman dan memberikan umpan balik. Kegiatan ini menekankan pada guru agar memberikan beberapa pertanyaan lisan atau tertulis kepada siswa dan memberikan respon terhadap jawaban siswa. Pemberian umpan balik dapat menggunakan secara lisan, tes, dan komentar tertulis.

Dari berbagai pandangan di atas berkaitan dengan pendekatan pembelajaran yang berbeda dapat dicermati bahwa pendekatan pembelajaran matematika memberikan kontribusi penting pada sajian materi matematika di kelas sehingga berdampak pada perolehan hasil belajar statistika siswa. Berdasarkan uraian latar belakang masalah berkaitan hasil belajar statistika siswa yang diajarkan melalui pendekatan problem posing, maka peneliti tertarik mengkaji lebih lanjut dalam bentuk suatu penelitian. Berdasarkan uraian tersebut, maka masalah pada penelitian ini dirumuskan, yaitu: (1) apakah hasil belajar statistika siswa yang diajarkan melalui pendekatan problem posing lebih tinggi daripada yang diajarkan melalui pendekatan pembelajaran langsung? dan (2) bagaimana respon siswa setelah proses pembelajaran statistika dengan pendekatan problem posing? Sejalan dengan latar belakang masalah dan rumusan masalah yang telah dikemukakan tersebut, maka penelitian bertujuan untuk memaparkan, yaitu: (1) hasil belajar statistika siswa yang diajarkan melalui pendekatan problem posing lebih tinggi daripada yang diajarkan melalui pendekatan pembelajaran 
langsung, dan (2) respon siswa setelah proses pembelajaran statistika dengan pendekatan problem posing.

Adapun manfaat penelitian diharapkan adalah: (1) sebagai kontribusi pemilihan pendekatan pembelajaran bagi guru agar menekankan keterampilan pengajuan soal matematika sehingga perolehan hasil belajar lebih optimal, dan (2) sebagai pemikiran bagi pihak relevan untuk melakukan riset lanjutan.

\section{METODE PENELITIAN}

Metode penelitian yang digunakan adalah penelitian eksperimen. Jenis kuasi eksperimen dengan rancangan post test only control group design. Populasi dalam penelitian ini adalah seluruh siswa kelas VIII MTsS Darul Hikmah Aceh Besar. Sampel penelitian ini yaitu kelas $\mathrm{VIII}_{1}$ dan $\mathrm{VIII}_{2}$ yang diambil dengan teknik total sampling. Karena kelas VIII terdiri dari 2 kelas saja dan kedua kelas kemampuannya relatif sama. Kelas VIII ${ }_{1}$ sebagai kelas eksperimen diajarkan melalui pendekatan problem posing dan kelas $\mathrm{VIII}_{2}$ diajarkan melalui pendekatan pembelajaran langsung.

Instrumen yang digunakan dalam penelitian ini adalah tes hasil belajar statistika, dan angket respon siswa. Tes hasil belajar statistika berupa soal essay yang disusun berdasarkan indikator yang ditetapkan dalam RPP. Dalam hal ini dilakukan satu kali tes, yaitu post test. Angket respon siswa berupa pernyataan yang berkaitan dengan tanggapan siswa setelah proses pembelajaran diajarkan pendekatan problem posing.

Analisis data penelitian berupa tes hasil belajar statistika berupa analisis inferensial melalui uji t dan data hasil respon siswa dianalisis melalui analisis deskriptif. Analisis hasil belajar statistika siswa, dilakukan pengujian hipotesis uji t satu pihak, adapun rumusan hipotesis statistik yaitu hipotesis nol $\left(\mathrm{H}_{0}\right)$ dan hipotesis alternatif $\left(\mathrm{H}_{2}\right)$ adalah sebagai berikut:

$\mathrm{H}_{0}: \mu_{1} \leq \mu_{2} \quad$ Hasil belajar statistika siswa yang diajarkan melalui pendekatan problem posing sama dengan atau lebih rendah daripada yang diajarkan melalui pendekatan pembelajaran langsung

$\mathrm{H}_{a}: \mu_{1}>\mu_{2} \quad$ Hasil belajar statistika siswa yang diajarkan melalui pendekatan problem posing lebih tinggi daripada yang diajarkan melalui pendekatan pembelajaran langsung.

Data hasil angket respon peserta didik yang diperoleh selanjutnya dianalisis dengan menggunakan rata-rata keseluruhan skor yang telah dibuat dengan model skala Likert. Penskoran ini menurut Sukardi (2004) sebaiknya menggunakan skala Likert, pilihan jawaban diberikan bobot nilai kuantitatif 4,3,2,1 untuk pertanyaan dan 1,2,3,4 untuk pertanyaan negatif. Untuk pertanyaan positif maka diberi skor 4 untuk sangat setuju, 3 untuk setuju, 2 untuk tidak setuju dan 1 untuk sangat tidak setuju. Sedangkan untuk pertanyaan negatif diberi skor sebaliknya yaitu 1 untuk sangat setuju, 2 untuk setuju, 3 untuk tidak setuju dan 4 untuk sangat tidak setuju. Respon peserta didik dapat dihitung dengan menggunakan rumus skor rata-rata. Kriterianya sebagai berikut:

$$
\begin{aligned}
& 3<\text { skor rata-rata } \leq 4=\text { sangat positif } \\
& 2<\text { skor rata-rata } \leq 3=\text { positif } \\
& 1<\text { skor rata-rata } \leq 2=\text { negatif } \\
& 0<\text { skor rata-rata } \leq 1=\text { sangat negatif }
\end{aligned}
$$




\section{HASIL}

Pengumpulan data penelitian dilakukan pada kedua kelas perlakuan. Pada kelas eksperimen diajarkan melalui pendekatan problem posing dan pada kelas kontrol diajarkan melalui pendekatan pembelajaran langsung. Setelah proses pembelajaran statistika telah selesai dilakukan pada kelas eksperimen dan kelas kontrol sebagaimana mestinya dan diberikan post test. Pengumpulan data post test hasil belajar statistika siswa dan data hasil angket respon siswa. Selanjutnya data diolah dan dianalisis dengan teknik analisis data yang telah ditetapkan. Data hasil analisis deskriptif post test berupa tes hasil belajar statistika siswa disajikan dalam bentuk Tabel 1 berikut ini.

Tabel 1 Data Tes Hasil Belajar Statistika Siswa

\begin{tabular}{ccc}
\hline Data & Kelas Eksperimen & Kelas Kontrol \\
\hline Rerata & 78 & 69,97 \\
\hline Simpangan baku & 14,4 & 10,38 \\
\hline Variansi & 209,21 & 107,77 \\
\hline
\end{tabular}

Dari Tabel 1 menunjukkan bahwa, rerata hasil post test berbeda antara kelas eksperimen dan kelas kontrol. Ternyata hasil rerata tersebut diperoleh kelas eksperimen lebih tinggi daripada kelas kontrol. Namun standar deviasi kelas kontrol lebih kecil daripada kelas eksperimen. Hasil data ini menunjukkan bahwa sebaran data kelas kontrol lebih baik daripada sebaran data kelas eksperimen. Selanjutnya data tes hasil belajar statistika siswa dilakukan uji normalitas data dengan menggunakan taraf signifikansi $\alpha=$ 0,05 seperti disajikan pada Tabel 2 berikut ini.

Tabel 2 Hasil Uji Normalitas Data Tes Hasil Belajar Statistika Siswa

\begin{tabular}{ccccc}
\hline \multirow{2}{*}{ Data } & \multicolumn{2}{c}{ Kelas Eksperimen } & \multicolumn{2}{c}{ Kelas Kontrol } \\
\cline { 2 - 5 } & $\boldsymbol{\chi}_{\text {hitung }}^{\mathbf{2}}$ & $\boldsymbol{\chi}_{\text {tabel }}^{\mathbf{2}}$ & $\boldsymbol{\chi}_{\text {hitung }}^{2}$ & $\boldsymbol{\chi}_{\text {tabel }}^{\mathbf{2}}$ \\
\hline $\begin{array}{c}\text { Uji normalitas data } \\
(\alpha=0,05)\end{array}$ & 5,30 & 9,49 & 1,26 & 9,49 \\
\hline
\end{tabular}

Tabel 2 menunjukkan bahwa uji normalitas data tes hasil belajar statistika siswa kelas eksperimen berdistribusi normal, yaitu $\chi_{\text {hitung }}^{2}<\chi_{\text {tabel }}^{2}$ yaitu 5,30<9,49. Demikian pula kelas kontrol diperoleh bahwa $\chi_{\text {hitung }}^{2}<\chi_{\text {tabel }}^{2}$ yaitu $1,26<9,49$ maka data tes hasil belajar statistika siswa berdistribusi normal. Hasil dari pengujian normalitas data dilanjutkan dengan uji homogenitas variansi dengan menggunakan taraf signifikansi $\alpha=0,05$ seperti disajikan pada Tabel 3 berikut ini.

Tabel 3 Uji Homogenitas Variansi Tes Hasil Belajar Statistika Siswa

\begin{tabular}{ccc}
\hline \multirow{2}{*}{$\begin{array}{c}\text { Data Tes Hasil Belajar Statistika } \\
\text { Siswa }\end{array}$} & \multicolumn{2}{c}{$\begin{array}{c}\text { Uji Homogenitas Variansi } \\
(\boldsymbol{\alpha}=\mathbf{0 , 0 5})\end{array}$} \\
\cline { 2 - 3 } & $\mathrm{F}_{\text {hitung }}$ & $\mathrm{F}_{\text {tabel }}$ \\
\hline $\begin{array}{c}\text { Kelas Eksperimen } \\
\text { Kelas Kontrol }\end{array}$ & 1,94 & 2,21 \\
\hline
\end{tabular}

Tabel 3 menunjukkan $\mathrm{F}_{\text {hitung }} \leq \mathrm{F}_{\text {tabel }}$ yaitu 1,94 $\leq 2,21$ bahwa tidak terdapat perbedaan varians antara kelas eksperimen dan kelas kontrol. Sehingga dapat dikatakan 
bahwa variansi tes hasil belajar statistika siswa pada kelas eksperimen dan kelas kontrol adalah homogen.

Langkah selanjutnya melakukan pengujian hipotesis dengan kriteria pengujian adalah terima $H_{a}$ jika $t_{\text {hitung }}>t_{\text {tabel }}$ dengan taraf signifikan $\alpha=0,05$ untuk harga $t$ yang lainnya $\mathrm{H}_{0}$ ditolak. Pengujian hipotesis dengan uji t pada taraf signifikan $\alpha=0,05 \mathrm{dan} \mathrm{dk}=35$, diperoleh hasil perhitungan $\mathrm{t}_{\text {hitung }}=2,45$ dan $\mathrm{t}_{\text {tabel }}=1,70$, sehingga 2,45 $>1,70$ atau $\mathrm{t}_{\text {hitung }}>$ $\mathrm{t}_{\text {tabel, }}$ maka dalam hal ini hipotesis $\mathrm{H}_{0}$ ditolak dan hipotesis $\mathrm{H}_{\mathrm{a}}$ diterima, yaitu hasil belajar statistika siswa yang diajarkan melalui pendekatan problem posing lebih tinggi daripada yang diajarkan melalui pendekatan pembelajaran langsung.

Selanjutnya pengumpulan, pengolahan dan analisis data angket respon siswa yang telah diisi oleh 20 siswa. Berdasarkan hasil perhitungan skor rata-rata sebesar 3,29. Dari kriteria kategori skor menunjukkan bahwa respon siswa sangat positif untuk setiap aspek yang direspon dari pembelajaran yang diajarkan melalui pendekatan problem posing.

\section{PEMBAHASAN}

\section{Hasil Belajar Statistika Siswa}

dari hasil penelitian menunjukkan bahwa rata-rata hasil belajar statistika siswa kelas eksperimen yang diajarkan melalui pendekatan problem posing sebesar 78 dan untuk kelas kontrol yang diajarkan melalui pendekatan pembelajaran langsung sebesar 69,97. Berdasarkan uji t dengan uji pihak kanan diperoleh bahwa $t_{\text {hitung }}>t_{\text {tabel }}$ yaitu 2,45 $>1,70$. Hasil perhitungan tersebut berarti $\mathrm{H}_{0}$ ditolak dan $\mathrm{H}_{a}$ diterima. Sehingga rata-rata hasil belajar statistika siswa yang diajarkan melalui pendekatan problem posing lebih tinggi dari pada hasil belajar statistika siswa yang diajarkan melalui pendekatan pembelajaran langsung. Hasil belajar statistika siswa yang lebih tinggi tersebut diasumsikan bahwa pendekatan problem posing memberikan kontribusi terhadap kemampuan siswa dalam menyelesaikan masalah statistika.

Perubahan perolehan hasil belajar statistika siswa yang diajarkan melalui pendekatan problem posing memberikan penekanan bahwa pendekatan pembelajaran harus menjadi perhatian dalam membelajarkan matematika sekolah. Sebagaimana diketahui bahwa problem posing sebagai suatu pendekatan pembelajaran yang melibatkan siswa dalam belajar untuk menyelesaikan masalahnya. Menurut Thobroni (2013) bahwa pendekatan tersebut mengharuskan siswa menyusun pertanyaan sendiri atau memecah suatu soal menjadi pertanyaan-pertanyaan yang lebih sederhana yang mengacu pada penyelesaian soal tersebut. Siswa harus menguasai materi dan urutan penyelesaian soal secara mendetail. Pelibatan siswa dalam pendekatan problem posing ditempatkan pada kelompok kecil yang heterogen terdiri atas 4 atau 5 siswa. Dalam kelompok tersebut tidak dibedakan jenis kelamin, suku, bangsa, atau tingkat kecerdasan siswa. Kelompok kecil yang heterogen secara kemampuan termasuk adanya siswa pandai, sedang, lemah dan dibangun kerjasama dan berbagi sesama antara satu dengan yang lainnya. Proses pembelajaran seperti itu melengkapi suasana problem posing siswa agar keaktifan, kreatif dan menumbuhkan rasa sosial yang tinggi dapat optimal. Kegiatan pembelajaran yang terencana antara proses dan hasil belajar tersebut yang berimbang akan dapat membentuk siswa yang berkembang dengan utuh sehingga potensi diri mereka dapat optimal (Sanjaya, 2007). 
Berbeda dengan pendekatan pembelajaran langsung yang proses pembelajaran terjadi karena adanya stimulus. Stimulus dapat berupa juga pengondisian lingkungan dan pembiasaan. Kuat atau lemahnya stimulus memberikan dampak pada perubahan tingkah laku siswa (Ahmad, 2012). Umumnya respon yang diperlihatkan cenderung pada sebatas mendengar, menyimak, dan memperhatikan saja. Otomatis dampak pada kemampuan masing-masing siswa jauh berbeda. Siswa yang lebih banyak mendengar dan menyimak secara seksama dimungkinkan dia lebih tinggi hasil belajarnya dibandingkan siswa yang tidak mendengarkan. Kecenderungan ini juga pada pola komunikasi antara guru dan siswa lebih banyak satu arah. Hal ini disebabkan karena posisi guru sebagai pemberi informasi dari bahan ajar sudah jadi. Siswa lebih banyak mendengarkan dan menyelesaikan masalah sesuai petunjuk guru berikan dan lebih banyak dilakukan secara individual. Kondisi seperti ini memungkinkan siswa memandang bahwa belajar matematika itu lebih banyak membosankan daripada menyenangkan. Tak bisa disangkal bahwa kondisi belajar matematika seperti ini banyak dialami oleh sebagian besar siswa di banyak sekolah.

\section{Respon Siswa}

Angket respon diberikan kepada siswa belajar statistika yang diajarkan melalui pendekatan problem posing. Kegiatan ini dilakukan pada akhir pertemuan setelah siswa menyelesaikan post test. Berdasarkan hasil analisis respon siswa terhadap pembelajaran statistika yang diajarkan melalui pendekatan problem posing diperoleh bahwa skor rata-rata sebesar 3,29 dengan kriteria sangat positif.

Skor rata-rata tersebut dapat dicermati dari hasil angket yang menyatakan bahwa siswa senang terhadap kegiatan pembelajaran statistika. Rasa senang siswa terhadap pembelajaran statistika menunjukkan bahwa pembelajaran ini menimbulkan rasa puas bagi siswa. Siswa mengharapkan pembelajaran menggunakan pendekatan problem posing juga diterapkan pada materi matematika yang lain. Rasa senang siswa juga disebabkan oleh adanya kerja sama dalam kelompok dalam menyelesaikan tugas pada LKPD, siswa juga merasa senang karena bisa mengekspresikan ide mereka sendiri dengan corak yang beragam bentuk dan bervariasi. Pengalaman belajar tersebut diperoleh siswa, karena keterlibatan siswa sendiri dalam berhadapan dengan pengalaman fisis, matematis-logis dan sosial yang disesuaikan dengan tingkat perkembangan kognitifnya (Suparno, 2001). Belajar yang menyenangkan ini seringkali sebagai penentu utama kualitas dan kuantitas belajar yang dapat terjadi. Kegembiraan bukan berarti menciptakan suasana kelas yang ribut dan penuh hura-hura. Namun kegembiraan berarti membangkitkan tingkat pemahaman dan hasil belajar matematika yang membahagiakan pada diri siswa. Disamping itu guru memegang peranan penting dalam pembelajaran statistika melalui pendekatan problem posing. Karena posisi guru dalam pendekatan tersebut lebih banyak sebagai fasilitator dan motivator.

\section{KESIMPULAN}

Berdasarkan hasil penelitian disimpulkan bahwa: 1) hasil belajar statistika siswa yang diajarkan melalui pendekatan problem posing lebih tinggi daripada yang diajarkan melalui pendekatan pembelajaran langsung berdasarkan hasil uji t diperoleh bahwa $t_{\text {hitung }}=2,45>$ $t_{\text {tabel }}=1,70$; dan 2) Respon siswa terhadap pembelajaran statistika setelah diajarkan melalui pendekatan problem posing sangat positif dengan skor rata-rata 3,29 


\section{DAFTAR PUSTAKA}

Afgani, Muhammad Win., Saputro, Bagus Ardi., \& Darmayasa, Jero Budi. (2016). Pembelajaran Matematika Menggunakan Pendekatan Problem Posing berbasis Komputer Pada Siswa SMA Kelas X. Infinity: Jurnal Ilmiah Program Studi Matematika STKIP Siliwangi Bandung, 5(1), 32-41. Retrieved form http://ejournal.stkipsiliwangi.ac.id/ index.php/infinity/article/view/189.

Afriansyah, E. A. (2017). Problem Posing sebagai Kemampuan Matematis. Mosharafa: Jurnal Pendidikan Matematika, 6(1), 163-180. Retrieved from https://journal.institut pendidikan.ac.id/index.php/mosharafa/article/view/mv6n1_15/308.

Ahmad, Zainal Arifin. (2012). Perencanaan Pembelajaran dari Desain sampai Implementasi. Yogyakarta: Pedagogia.

BNSP Kemendikbud. (2015). Data Hasil Ujian Nasional Tabun Pelajaran 2014/2015. Retrieved from http://bsnp-indonesia.org.

Brown, S. I. \& Walter, M. I. (2005). The Art of Problem Posing. (3rd ed.). Mahwah, New Jersey: Lawrence Erlbaum Associates, Inc., Publishers. Retrieved from https://www.taylorfrancis.com/books/9781135612245.

Daryati, Dewi., Nugraha., \& Sutarni, Nani. (2018).Pengaruh Penggunaan Metode Problem Posing terhadap Kemampuan Memecahkan Masalah. Jurnal Pendidikan Ilmu Sosial, 27(1), 31-42. Retrieved from http://ejournal.upi.edu/index.php/jpis/ article/view/11048.

Djamarah, Syaiful B. \& Aswan. (2002). Strategi Belajar Mengajar. Jakarta: Rineka Cipta.

Hudojo, Herman. (1990). Strategi Belajar Mengajar Matematika, Cetakan II. Malang: IKIP Malang.

Işik, C., Kar, T., Yalçin, T., \& Zehir, K. (2011). Prospective Teachers' Skills In Problem Posing With Regard To Different Problem Posing Models. In Procedia- Social and Behavioral Sciences, 15, 485-489. doi:/10.1016/j.sbspro.2011.03.127.

Juano, Asterius., \& Pardjono. (2016). Pengaruh Pembelajaran Problem Posing Terhadap Kemampuan Berpikir Kritis dan Komunikasi Matematis Siswa Kelas V SD. Jurnal Prima Edukasia, 4(1), 46-53. Retrieved from http://journal.uny.ac.id/index.php/ jpe/article/view/7801/pdf

Kardi, S. \& Nur, M. (2000). Pengajaran Langsung. Surabaya : University Press.

Kurniawan. (2003). Fokus Matematika. Jakarta : Penerbit Erlangga.

Nuralam \& Eliyana. (2017). Penerapan Pendekatan Saintifik terhadap Kemampuan Pemecahan Masalah Matematika di SMAN 1 Darul Imarah Aceh Besar. Jurnal Ilmiah Didaktika FTK UIN Ar-Raniry, 18(1), 64-76. Retrieved from https://jurnal.ar-raniry.ac.id/index.php/didaktika/index.

Pittalis, M., et al. (2004). A Structural Model for Problem Posing. Proceedings of The 28th Conference of the International Group for The Psychology of Mathematics Education, 4, 49-56. Retrieved from http://ww.kurims.kyoto-u.ac.jp/EMIS/.../RR/RR058_Pittalis.pdf.

Purwanto. (2009). Evaluasi Hasil Belajar. Yogyakarta: Pustaka Pelajar. 
Robert M. Gagne, Leslie J. Briggs and Walter W. Wagner. (1979). Principles of Instructional Design. New York: Holt, Rinehart and Winston. Retrieved from https://hcs64.com/files/Principles\%20of\%20instructional\%20design.pdf.

Rosli, Roslinda., Goldsby, Dianne., \& Capraro, Mary Margaret. (2013). Assessing Students' Mathematical Problem-Solving And Problem-Posing Skills. Asian Social Science, 9(16), 54-60. Retrieved from http://dx.doi.org/10.5539/ass.v9n16p54.

Ruseffendi, E.T. (2005). Dasar-Dasar Matematika. Bandung: Tarsito.

Sanjaya, Wina. (2007). Strategi Pembelajaran: Berorientasi Standar Proses Pendidikan. Jakarta: Kencana Prenada Media Grup.

Schunk, Dale H. (2012). Learning Theories an Educational Perspective, Edisi Keenam, Penterjemah Eva Hamdiah dan Rahmat Fajar, Yogyakarta: Pustaka Pelajar.

Silver, E. A. \& Cai, J. (1996). An Analysis of Arithmetic Problem Posing by Middle School Students. Journal for Research in Mathematics Education, 27(5), 521-539. Retrieved from https://www.jstor.org/stable/749846

Sudjana, Nana. (1999). Penilaian Hasil Proses Belajar Mengajar. Bandung: PT Remaja Rosdakarya.

Sukardi. (2004). Metodologi Penelitian: Kompetensi dan Prakteknya. Jakarta: Bumi Aksara.

Sunarto \& Hartono, B. Agung. (2006). Perkembangan Peserta Didik. Jakarta: PT Rineka Cipta.

Suparno, Paul. (2001). Teori Perkembangan Kognitif Jean Piaget. Yogyakarta: Penerbit Kanisius.

Thobroni, Muhammad., dkk. (2013). Belajar dan Pembelajaran Pengembangan Wacana dan Praktek Pembelajaran dalam Pembangunan Nasional. Jogjakarta: Ar-Ruzz Media.

Walpole, Ronald E. (1993). Pengantar Statistika. Jakarta: PT Gramedia Pustaka Utama. 